\title{
Podocnemis lewyana Duméril 1852 - Magdalena River Turtle
}

\author{
Vivian P. Páez ${ }^{1}$, Adriana Restrepo ${ }^{1}$, \\ Mario Vargas-Ramirez ${ }^{2,3}$, AND Brian C. BOCK ${ }^{1}$ \\ ${ }^{1}$ Instituto de Biología, Universidad de Antioquia, Medellín, Colombia \\ [vppaez@gmail.com; restrepoadriana78@gmail.com; brianbock1@gmail.com]; \\ ${ }^{2}$ Museum of Zoology, Natural History State Collections Dresden, Königsbrücker Landstr. 159, \\ D-01109,Dresden, Germany [mavargas@yahoo.com]; \\ ${ }^{3}$ Fundación Biodiversa Colombia, Bogotá, Colombia
}

\begin{abstract}
Summary. - Podocnemis lewyana, the Magdalena River turtle (Family Podocnemididae), is a medium to large-sized river turtle confined to the Sinú,San Jorge, Cauca, and Magdalena river drainages in Colombia, making it a biogeographic anomaly, being the only South American podocnemid turtle to occur northwest of the Andes Mountains instead of inhabiting the Orinoco, Essequibo, or Amazon drainages. The species is currently classified as Endangered on the IUCN Red List due to the combined effects of habitat modification and the heavy exploitation of adults and eggs for consumption as well as some exploitation of hatchlings for the illegal pet trade. Recent analysis suggests it should be uplisted to Critically Endangered. Information on the species' natural history has been fragmentary, but recent field and laboratory studies have generated more detailed information on $P$. lewyana systematics, ecology, distribution, trends in abundances, and levels of genetic diversity within and among populations. Podocnemis lewyana is primarily herbivorous as adults and nests in the dry season, preferentially but not exclusively on sandy beaches. Nests suffer heavy human and natural predation and also experience infestations by invertebrates and fungi. Sex ratios in the field covary with nest temperatures, and laboratory studies have confirmed the existence of temperaturedependent sex determination in this species and a high pivotal temperature $\left(33.4^{\circ} \mathrm{C}\right)$. These studies have also demonstrated incubation temperature and maternal effects on hatchling size, mass, and growth rates. In most regions, $P$. lewyana population densities are low, with low levels of genetic diversity and no evidence of phylogeographic differences among sites. Existing legislation meant to protect the species is largely unenforced. However, recent attempts to support community-based conservation initiatives and educational activities make it more likely that well-founded management projects may be possible in the near future.

Distribution. - Colombia. Restricted to the Sinú,San Jorge, Cauca, and Magdalena river drainages in northwestern Colombia.

Synonymy. - Podocnemis lewyana Duméril 1852.

SUBSPECIES. - None recognized. Genetic analyses demonstrate no significant phylogeography.

STATUS. - IUCN 2008 Red List: Endangered (EN A1bd) (assessed 1996, needs updating); CITES: Appendix II; Colombian Red Book: Endangered.
\end{abstract}

Taxonomy. - Podocnemis lewyana was described by Duméril (1852) based on three syntype specimens, with a type locality of Santa Fé de Bogotá (erroneously cited as being part of Venezuela). Williams (1954) later identified one of the syntypes as being a specimen of Podocnemis vogli, and designated one of the remaining two valid syntypes as lectotype (MNHN 8985; Iverson, 1995). No subspecies are recognized. In a recent molecular phylogeny of the family Podocnemididae, $P$. lewyana was revealed to be one of the species that forms the crown clade of the genus: P. unifilis $+(P$. erythrocephala $+P$. lewyana) (Vargas-Ramirez et al. 2008).

Description. - The Magdalena River turtle is a medium to large-sized,sexually dimorphic species, with adult females ranging from 480-600 $\mathrm{mm}$ in curved carapace length (CL), or $460 \mathrm{~mm}$ straight $\mathrm{CL}$, frequently with a mass of more than $8 \mathrm{~kg}$. Males are smaller, reaching a straight CL of approximately $320 \mathrm{~mm}$ (Ernst and Barbour 1989, Castaño-Mora 2002). Males have longer and thicker tails (Iverson 1995) and, in contrast to females, the cloaca is located posterior to the marginal scutes. Also, females have a depression in the posterior carapace, while males have a depression in the middle of the plastron (Hurtado 1973). The anal notch angle is more acute in males than in females; moreover, the anal suture is shorter in males (Gallego-García 2004). Finally, there is sexual color dimorphism; the head scales in males are grayish brown, while females have a more reddish brown color (Gallego-García 2004).

The carapace has 24 marginal, five vertebral, and eight costal scutes. In adults, the carapace is oval and flattened, 


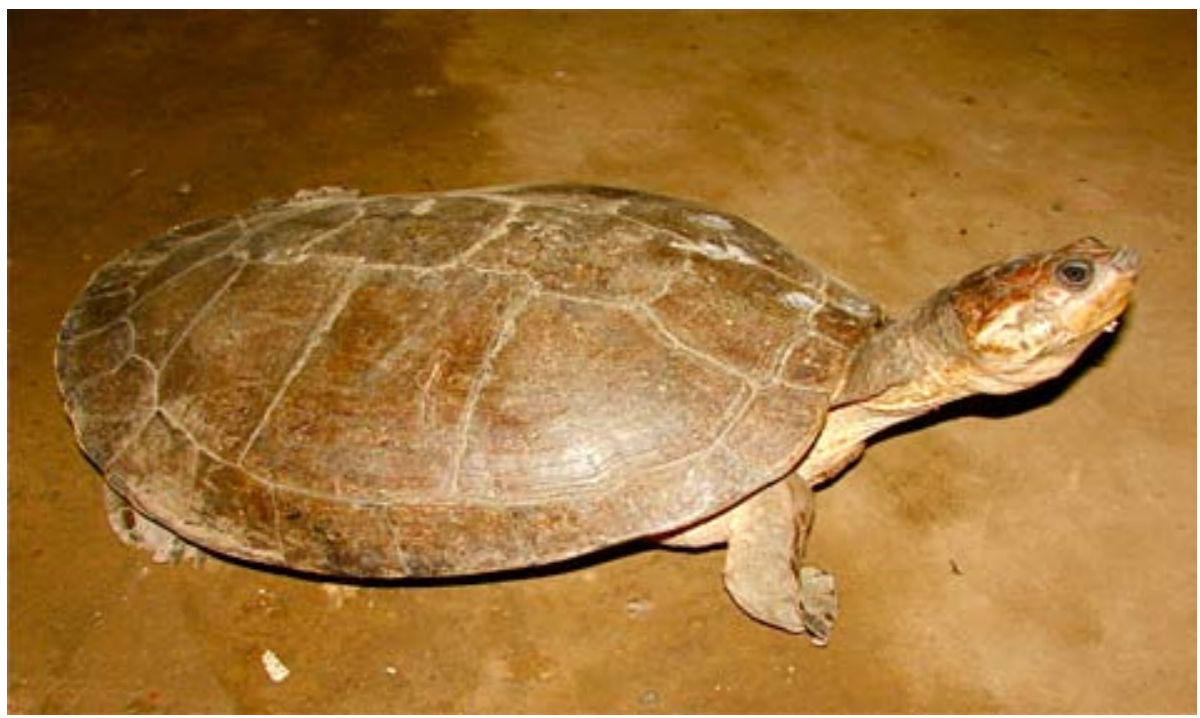

Figure 1. Podocnemis lewyana, nesting adult female from the Chicagua River, Colombia. Photo by Alejandra Cadavid.

usually without keels or cervical indentations (although juveniles may have keels; Ernst and Barbour 1989). The edge of the carapace is slightly raised on the sides but may be level along the posterior end (Castaño-Mora 2002). The carapace is wider in its posterior third and varies from gray to olive brown, occasionally with dark spots. The plastron is smaller than the carapace and is usually a yellowish-green color with dark spots on its anterior and middle portions (Castaño-Mora 2002). Podocnemis lewyana has the most elongate head of all the species in the genus, possessing a groove between the orbits. The upper jaw is slightly rounded and lacks notches. The interparietal scale is very broad and heart-shaped. The subocular scales are present, as are two barbels below the lower jaw. The species lacks a nuchal indentation. Neonates and juveniles posses an olive gray head with a light cream to yellow band between the posterior edges of the eyes and the tympanum. The head of adults is brown, as is the region between the posterior edges of the eyes, with the tympanum clearer, especially in males. In all size classes, the neck and extremities are gray to olive color, while the jaw varies from dark yellow to bone color and the

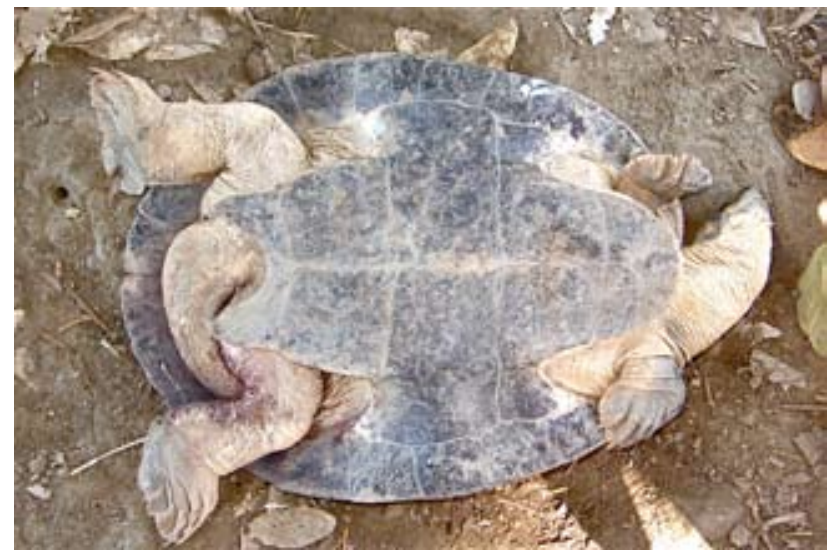

Figure 2. Podocnemis lewyana, adult male from the Chicagua River, Colombia. Photo by Alejandra Cadavid. throat is yellowish. Podocnemis lewyana has the $2 n=28$ karyotype common to all members of the genus (Rhodin et al. 1978).

Distribution. - Endemic to Colombia with its presence documented in the Sinú, San Jorge, Cauca, and Magdalena

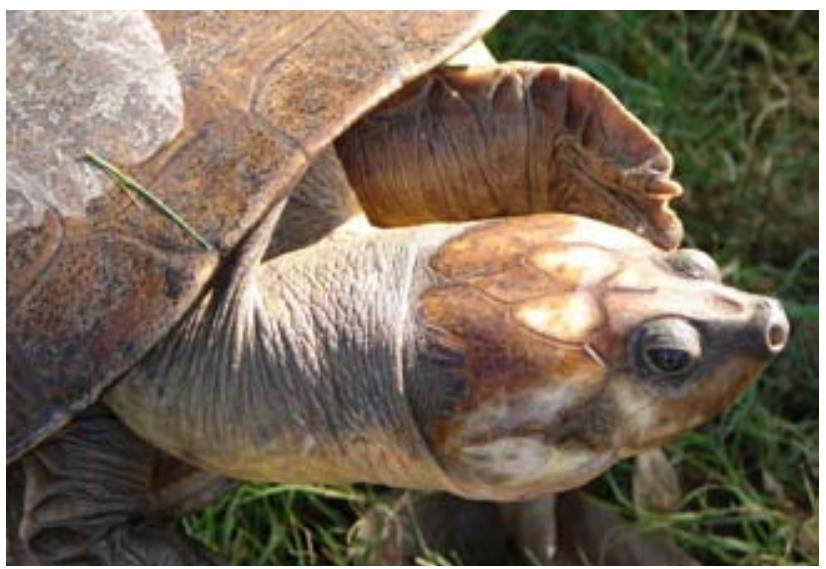

Figure 3. Podocnemis lewyana, adult female from the Chicagua River, Colombia. Photo by Alejandra Cadavid.

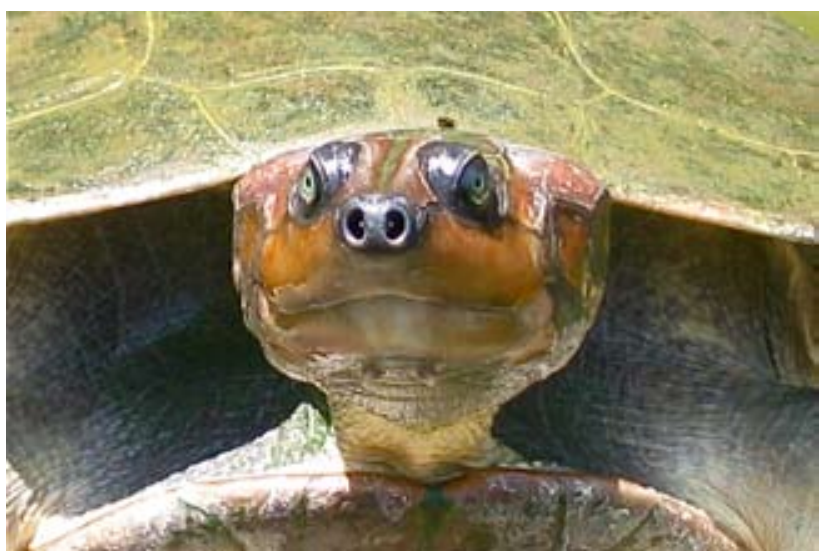

Figure 4. Podocnemis lewyana, captive adult female of unknown origin. Photo from Santa Marta, Colombia, by Vivian Páez. 


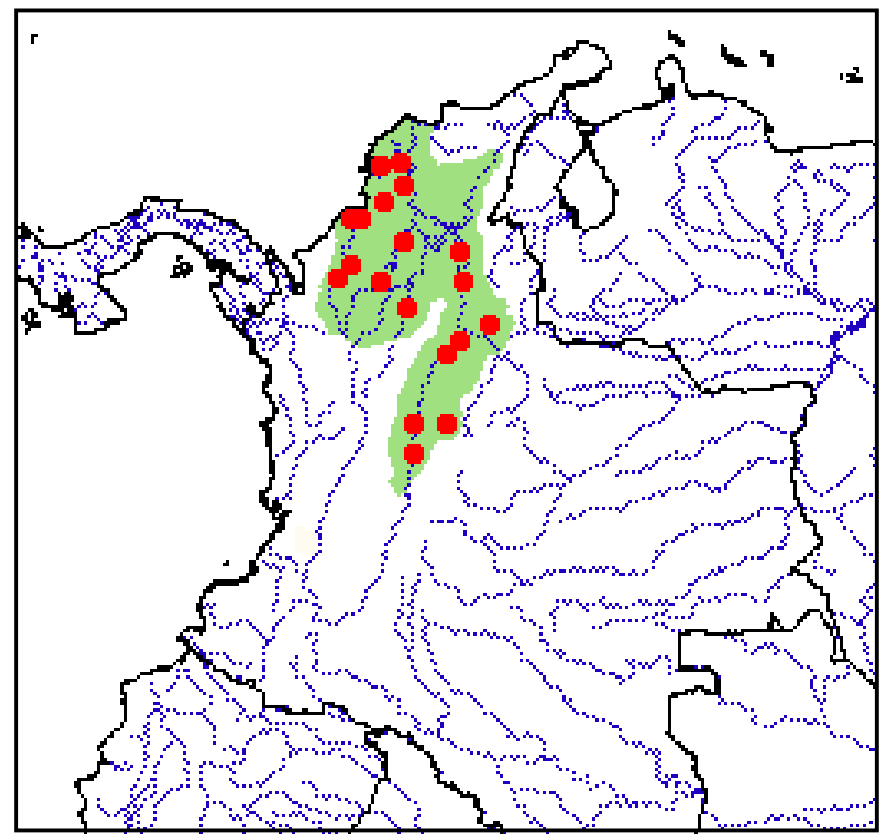

Figure 5. Distribution of Podocnemis lewyana in Colombia in northwestern South America. Red points = museum and literature occurrence records based on Iverson (1992) plus more recent and authors' data; green shading = projected distribution based on GIS-defined hydrologic unit compartments (HUCs) constructed around verified localities and then adding HUCs that connect known point localities in the same watershed or physiographic region, and similar habitats and elevations as verified HUCs (Buhlmann et al., unpubl. data), and adjusted based on authors' data.

river drainages (Rueda-Almonacid et al. 2007). This distribution makes it a biogeographic anomaly, being the only South American podocnemid turtle to occur northwest of the Andes Mountains instead of inhabiting the Orinoco, Essequibo, or Amazon drainages. Also, there are anecdotal records of its occurrence in the Ranchería and Cocorná rivers (Hurtado 1973; Rhodin et al. 1978; Restrepo et al. 2008). Its distributional limits are the Caribbean Sea to the north, Tolima Department to the south, and Antioquia Department to the west. Its range to the east may have been extended by its introduction into the Tarra River of Venezuela by Colombian colonists (Pauler and Trebbau 1995).

Habitat and Ecology. - Podocnemis lewyana is primarily seen along the banks of rivers, although it is also possible to find individuals in small tributaries, lagoons, and flooded areas connected to rivers. Individuals are of-

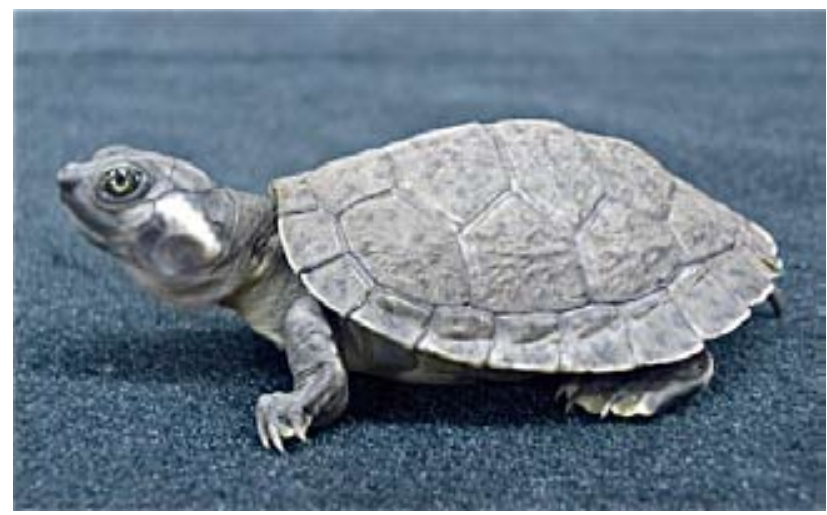

Figure 6. Podocnemis lewyana, hatchling from the Chicagua River, Colombia. Photo by Lina Hinestroza. ten observed basking on banks or fallen trunks along the shoreline, either alone or in groups including various size classes (Gallego-Garcia and Castaño-Mora 2008; Restrepo et al. 2008). Smaller individuals tend to occur in shallower, more turbid waters or in flooded pastures (Gallego-García and Castaño-Mora 2008).

Observations of diet in captivity have shown P.lewyana to be primarily herbivorous, but they also opportunistically take animal matter, and juveniles even pursue and consume small fish (Methner 1989; Páez, unpubl.data). Neustophagia has not been observed (Rhodin et al. 1981). An ongoing master's thesis project recently examined the stomach contents of seven adult females obtained during the nesting season, and they contained $99 \%$ vegetable matter by volume, with limited fragments of insect and snail body parts, implying they are only accidentally omnivorous (Lenis, unpubl. data). This study also confirmed a previous report (Brooks 1976) of infestation of $P$. lewyana stomachs by the digenean Neodeuterobaris pritchardae and found four new species of digeneans occurring in P. lewyana stomachs (Nematophila venezuelensis, Pseudonematophila momposina), large intestines (Nematophila argentinum), and small intestines (Telorchis hagmanni).

Nesting Ecology. - Adult females generally nest in open, sandy beaches within $15 \mathrm{~m}$ of the shoreline, although they also nest on exposed river banks and may nest as far as $39 \mathrm{~m}$ from the shore (Correa-Hernández 2006; Cano 2007). In the middle Magdalena drainage, the nesting season is during the primary dry season, from December to May, with a peak in March. Local residents also claim there is a secondary nesting period in the shorter second- 
ary dry season (veranillo) in July and August, but this has not yet been confirmed. In the Prado River of the upper Magdalena drainage, the main nesting period is from June to September and a secondary nesting period occurs from December to May (Vargas-Ramirez, unpubl. data). In the Sinú River, two seasons also have been documented in December to March and June to August (Gallego-García and Castaño-Mora 2008). There is no information yet available concerning whether females lay multiple clutches per year, as is known for other members of the genus (Soini 1995), but the existence of the secondary nesting season would make this possibility seem likely.

Mean nest depth is $20 \mathrm{~cm}$. Nest chambers are asymmetrically bottle-shaped, with oval entrances leading to chambers that slope off to one side. Clutch sizes vary from 10 to 31 eggs (Dahl and Medem 1964; Medem 1965; Castaño-Mora 1986; Correa-Hernández 2006; Cano 2007; Gallego-García and Castaño-Mora 2008) with a mean clutch size in the Mompos Depression of 20.5 eggs $(n=64$ nests; CorreaHernández 2006; Cano 2007). Eggs vary from roundish to ellipsoid with a slightly flexible parchment texture and pallid rosy gray color that turns to chalk white a few days following oviposition.

In addition to eggs lost to human egg-hunters, nests are depredated by lizards (Tupinambis teguixin; Teiidae), domestic dogs, pigs, and trampled by cattle. It also is common to find nests infested by ants, hemipterans, coleopterans, dipterans, and fungi (Correa-Hernández 2006; Cano 2007); however, it is not know whether these observations represent cases of genuine predation, or of opportunistic scavenging of embryos that perished for other reasons.

Overall, the mean incubation temperature of nests in the Mompos Depression was $32.8^{\circ} \mathrm{C}$ and was strongly correlated with incubation period, which averaged 59 days $(n=32)$. However, mean nest temperatures varied among years, producing concomitant changes in the sex ratios of the hatchlings produced (Páez et al., in press). A mean nest temperature of $31.4^{\circ} \mathrm{C}(\mathrm{SD}=1.47)$ during the middle trimester in 2005 produced a 1:1 male:female sex ratio; whereas a mean nest temperature of $34.0^{\circ} \mathrm{C}(\mathrm{SD}=1)$ during the middle trimester in 2006 produced a 1:8.4 male:female sex ratio (Páez et al., in press).

Temperature-Dependent Sex Determination. - The previous results imply that $P$. lewyana has temperaturedependent sex determination, which our recent studies of $P$. lewyana eggs incubated under constant humidity and temperature conditions in the laboratory have confirmed. The fact that, with both controlled incubation conditions in the lab and under natural incubation conditions in the field, we obtained a male-biased sex ratio at incubation temperatures below $32.8^{\circ} \mathrm{C}$ supports our conclusion that the pivotal temperature for this species is near $33.4^{\circ} \mathrm{C}( \pm 0.4)$, and that the transitional range is very narrow. Incubation temperature not only influenced hatchling sex ratios, but also other important fitness attributes, such as initial hatchling size and mass and subsequent growth rates (Páez et al., in press). Maternal effects also are important in influencing the sex ratio, size, mass, and growth rates of P.lewyana clutches (Páez, unpubl. data).

Population Genetics. - Vargas-Ramirez et al. (2006, 2007a) examined the mitochondrial cytochrome b gene from turtles collected from the four main drainages inhabited by $P$. lewyana (Sinú, San Jorge, Cauca, and Magdalena rivers), and found only two haplotypes that differed by a single nucleotide substitution, with no evidence of phylogeographic structure among these sites. An analysis of 22 allozyme loci (Restrepo 2008, Restrepo et al., in press) in individuals obtained from two sites within the Mompos Depression of the Magdalena River drainage only identified one polymorphic locus that did not exhibit significant allele frequencies among the sites. Both sites had significant heterozygote deficiencies at this locus. Thus, both studies were consistent in their conclusion that $P$. lewyana has low levels of genetic variability and no evidence of genetic population structure on a micro or macro-geographic scale, and the latter study suggested some level of inbreeding on a local scale.

Population Status. - This species has been classified internationally (IUCN 2008) and in Colombia (Castaño-Mora 2002) as Endangered, although these two classifications used differing criteria to establish threat levels.Podocnemis lewyana also is listed in Appendix II of CITES (CITES 2003), as are all other species in the genus. However, recent studies on the extent of recent range reductions and demographic declines (Gallego-García and Castaño-Mora 2008; Restrepo et al. 2008) argue that its classification should be uplisted to Critically Endangered. Many extant populations throughout the distributional range of the species currently face heavy subsistence and commercial exploitation and several show apparent low densities (Vargas-Ramirez et al. 2006). Some populations in the upper San Jorge River have already been extirpated (Vargas-Ramirez et al. 2006). An isolated population of $P$. lewyana also occurs above the Rodrigo Echandía Hydroelectric Dam located on the Prado River in Tolima Department in the upper Magdalena drainage.

Threats to Survival. - Several factors that affect populations of $P$. lewyana have been identified throughout its distributional range: 1) habitat destruction and pollution; 2) traditional utilization and consumption; 3) commercial exploitation; and 4) hydrological changes due to dams (GallegoGarcia 2004; Vargas-Ramirez et al. 2006, 2007b). Pastures and plantations have replaced original forest throughout a large portion of its territory. At urban centers and localities where extensive agriculture is the principal human activity (e.g., the upper Magdalena River), pollution of beaches and water bodies is common. Podocnemis lewyana is used as a source of protein for local people throughout its range. Various capture techniques are used, including hunting adult females with dogs on land during the nesting season, or in water by setting nets and hooks baited with plantain, or diving for individuals along the bottom of canals. In several fishing villages, turtles are also considered important for traditional medicinal purposes. In these communities, it is believed that consumption of turtles helps women to recover after preg- 
nancy, cures skin and eye diseases, confers longevity and strength, and serves as an aphrodisiac. The nesting season includes Easter week each year, when hunting pressures rise notably to satisfy the demand for "white meat" in the large cities on the nearby Caribbean coast. In the lower Magdalena and Sinú rivers, some people exclusively dedicate their time to the capture, transport, and sale of turtles and eggs. Adults are sold for between 10,000 to 25,000 pesos (\$US 5-14) and eggs are sold for between 700 to 1200 pesos each (\$US 0.40-0.60).

In the Sinú and Prado rivers (the Prado is a tributary of the upper Magdalena River), hydroelectric dams have been constructed. Whenever water is released to produce energy during the dry season, beaches that were exposed become submerged.Flooding may last for several days and several of these flooding episodes may occur during a single dry season. The impact of these events has never been evaluated but it is likely that thousands of eggs are inundated and drowned every year (Gallego-García and Castaño-Mora 2008).

In April and May, when neonates begin to emerge from the nests, they also are hunted with the objective of selling them in the illegal pet trade (Castaño-Mora 1986, 1997; Rueda-Almonacid 1999). Moreover, habitat degradation caused by draining wetlands for agricultural or ranching ventures and the sedimentation of other water bodies seriously jeopardizes the survival chances of P.lewyana (Castaño-Mora 1997, 2002; Rueda-Almonacid 1999).

Conservation Measures Taken. - Colombia prohibits the commercial exploitation of this species, as well as the collection of its eggs or hatchlings, by Resolution 0219 of the Ministry of Agriculture in 1964. Also, Resolution 126 by the Executive Directorate of the Regional Autonomous Corporation of the Magdalena and Sinú Valleys in 1965 declared a closed season, prohibiting the sale or purchase of this species on a national scale. However, these legislative acts have not been accompanied by effective implementation programs and they remain largely unenforced. At present, there are no protected areas within the range of the species.

Conservation Measures Proposed. - Despite its biogeographic, ecological, and economic importance, research and conservation activities focusing on P. lewyana to date have been few and disarticulated, failing to benefit the long-term viability of surviving populations. The protection of this species should be a national priority, with complimentary multidisciplinary projects oriented towards providing public education and awareness, as well as the biological and social information necessary to permit the design of effective management plans. Further evaluations of the impacts that the identified threats are causing also should be a high priority. In a survey of 18 populations, Restrepo et al. (2008) found that only one had an apparently high abundance of adults (the Río Chicagua population), arguing that this region should be considered for some form of protection status.

Captive Husbandry. - Since the 1990s, the biologist Miguel Rodriguez has been successfully reproducing $P$. lewyana in captivity on a private reptile farm belonging to the Fundación Pizano, S.A. in Zambrano, Bolivar Department, Colombia, although nothing concerning this project has been published to date.

Current Research. - The Grupo Herpetologico de Antioquia of the Instituto de Biología of the Universidad de Antioquia is carrying out ecological studies of P. lewyana in the middle Magdalena River drainage and laboratory studies that make up the project "Maternal and paternal effects on sex ratios and other fitness components in neonates of the river turtle Podocnemis lewyana" and also is conducting a study on the "Demographic structure of the endangered turtle Podocnemis lewyana (Podocnemididae) in the Chicagua Branch of the Magdalena River, Colombia". VargasRamirez and Fritz from the Museum of Zoology, Dresden, Germany, are currently performing a complete $P$. lewyana population genetics evaluation using nDNA microsatellites and D-loop mtDNA markers. The Fundación Biodiversa Colombia and the Instituto de Ciencias Naturales/Universidad Nacional de Colombia are currently conducting the project "Actions towards the protection and conservation of the endangered endemic freshwater turtle, Podocnemis lewyana, in the upper Magdalena River, Colombia”, which involves educational and awareness raising activities and biological research. Finally, communities in the Cocorná River and Puerto Berrío of the upper Magdalena River claim to have protection plans and preliminary head-starting programs underway (Restrepo et al. 2008).

Acknowledgments. - We would like to thank colleagues who shared information with us in the preparation of this account and the logistic and financial support of the Universidad de Antioquia, the Instituto de Ciencias Naturales of the Universidad Nacional de Colombia, the Fundación Biodiversa Colombia, the Conservation Leadership Program, the Cleveland Zoological Society, Ideawild, and the Turtle Conservation Fund.

\section{LITERATURE CITED}

BRooks, D.R. 1976. Neodeuterobaris pritchardae gen et sp. N. (Digenea: Microscaphidiidae) in a sideneck turtle, Podocnemis lewyana Dumeril 1852, from Colombia. Journal of Parasitology, 62:426-428.

CAno, A.M. 2007. Algunos de los aspectos de la ecología reproductiva de la tortuga de río Podocnemis lewyana (Testudinata: Podocnemididae) en el río Chicagua, Depresión Momposina, (Bolivar, Colombia). Tesis de pregrado, Instituto de Biología, Universidad de Antioquia, Medellín, Colombia.

CAstaño-Mora, O.V. 1986. Contribución al conocimiento de la reproducción de Podocnemis lewyana Dumeril (Reptilia: Quelonia: Pelomedusidae). Caldasia 15:665-667.

CASTAÑo-Mora, O.V. 1997. Status of the tortoises and freshwater turtles of Colombia. In: Van Abbema, J. (Ed.). Proceedings: Conservation, Restoration, and Management of Tortoises and Turtles - An International Conference. New York Turtle and Tortoises Society, New York, NY, pp. 302-306.

CAStaño-Mora,O.V.2002.Podocnemis lewyana.In: Castaño-Mora, O.V.(Ed.). Libro Rojo de Reptiles de Colombia, Ministerio del Medio Ambiente, Bogotá, Colombia, p. 92. 
CITES. 2003.Appendices I,II, and III.www.cities.org/eng/append/ appendices.shtml. (15 Sept. 2004).

Correa-Hernández,J.C.2006.Ecología de las tortugas Podocnemis lewyana (Podocnemidae) y Trachemys callirostris callirostris (Emydidae) en Isla Pava, Ciénaga La Rinconada, Depresión Momposina, Colombia. Tesis de pregrado,Instituto de Biología, Universidad de Antioquia, Medellín, Colombia.

Dahl, G. and Medem, F. 1964. Los reptiles acuáticos de las hoyas del Sinú. In: Informe sobre la Fauna Acuática del río Sinú. Corporación Autónoma Regional de los Valles de la Magdalena y Sinú (CMV). pp. 101-151.

DUMÉRIL, A. 1852. Description des reptiles nouveaux ou imparfaitement connus de la collection du Muséum d'Histoire Naturelle, et remarques sur la classification et les charactères des reptiles. Archives d'Muséum d'Histoire Naturelle, Paris 6:209-264.

ERnst, C. AND BARBour, R. 1989. Turtles of the World. Smithsonian Institution Press, Washington D.C., 313 Pp.

GaLlEGO-GarCia, N. 2004. Anotaciones sobre la historia natural de la tortuga de río Podocnemis lewyana en el río Sinú, Córdoba, Colombia.Tesis de pregrado, Universidad Nacional de Colombia, Bogotá, Colombia.

Gallego-Garcia, N., and Castaño-Mora, O. 2008. Ecology and status of the Magdalena River turtle, Podocnemis lewyana, a Colombian endemic. Chelonian Conservation and Biology 7:37-44.

Hurtado, S. N. 1973. Algunos aspectos bioecológicos de Podocnemis lewyana (Dumeril, 1984) (Testudinata: Pleurodira: Pelomedusidae 1830). Biol 1. Centro de Investigaciones Biológico Pesqueras del Río Magdalena. La Dorada, Caldas, Colombia.

IUCN. 2008. 2008 IUCN Red List of Threatened Species. www. iucnredlist.org.

Iverson, J.B. 1995. Podocnemis lewyana. Catalogue of American Amphibians and Reptiles 605:1-3.

Medem, F. 1965. Bibliografía comentada de reptiles colombianos. Revista de la Academia Colombiana de Ciencias Exactas, Físicas y Naturales 12:299-346.

Methner, K. 1989. Die Schildkröten des unteren Rio Magdalena (Kolumbien). Sauria 11:9-11.

PÁez, V.P., Correa, J.C., CANo, A.M. , AND Bock, B.C. In press. A comparison of maternal and temperature effects on sex, size and growth of hatchlings of the Magdalena River turtle (Podocnemis lewyana) incubated under field and laboratory conditions. Copeia.

Pauler, I. and Trebbau, P. 1995. Erstnachweis von Podocnemis lewyana Duméril, 1852 (Testudines) in Venezuela. Salamandra 31:181-186.

Restrepo, A. 2008. Diferencias poblacionales y estado de conservación de la tortuga de río, Podocnemis lewyana, en la Depresión Momposina, Colombia. Masters thesis, Insituto de Biología, Universidad de Antiquia, Medellín, Colombia.

Restrepo,A., PÁez, V.P., LóPez, C., AND Bock, B.C. 2008. Distribution and status of Podocnemis lewyana in the Magdalena river drainage of Colombia. Chelonian Conservation and Biology $7: 45-51$.

Restrepo, A., Bock, B.C., And PÁez, V.P. In press. Genetic variability in the Magdalena River turtle, Podocnemis lewyana (Duméril, 1852), in the Mompos Depresion, Colombia. Actualidades Biológicas.

Rhodin, A.G.J., MitTermeier, R.A., Gardner, A.L., ANd Medem,
F. 1978. Karyotypic analysis of the Podocnemis turtles. Copeia 1978:723-728.

Rhodin, A.G.J., Medem, F., ANd Mittermeier, R.A. 1981. The occurrence of neustophagia among podocnemine turtles. British Journal of Herpetology 6:175-176.

RuEDA-Almonacid., J.V. 1999. Anfibios y reptiles amenazados de extinción en Colombia. Revista de la Academia Colombiana de Ciencias Exactas, Físicas y Naturales. 23 (Volumen Suplemento Especial):475-498.

Rueda-Almonacid, J.V., Carr, J.L., Mittermeier, R.A., RodríguezMahecha, J.V., Mast, R.B., Vogt, R.C., Rhodin, A.G.J., De La Ossa-Velásquez, J., Rueda, J.N., and Mittermeier, C.G. 2007. Las tortugas y los cocodrilianos de los países andinos del trópico. Bogotá, Colombia: Editorial Panamericana, Formas e Impresos, Serie de guías tropicales de campo No. 6, Conservación Internacional, $538 \mathrm{pp}$.

Sorni, P. 1995. Bioecología de la taricaya (Podocnemis unifilis): datos nuevos y actualizaciones. In: Soini, P., Tovar, A., and Valdez, U. (Eds.). Reporte Pacaya-Samiria. Investigaciones en la Estación Biológica Cahuana, 1979-1994. Centro de Datos para la Conservación, Universidad Nacional Agraria La Molina, Iquitos, Perú, pp. 353-361.

Vargas-Ramirez,M., Y.Chiari, O.V.CAstaño-Mora, and MEnKen, S.B.J. 2006. First genetic survey on the Magdalena's endemic freshwater turtle Podocnemis lewyana (Testudines, Podocnemididae) and its relation with human communities. Consequences for the species conservation. Final report, 49 pp. www.fundacionbiodiversa.org/proyectos_tortuga.htm.

Vargas-Ramirez, M.,Chiari, Y., CASTaño-Mora, O., AND MenKen, S. 2007a. Low genetic variability in the endangered Colombian endemic freshwater turtle Podocnemis lewyana (Testudines, Podocnemididae). Contributions to Zoology 76:1-7.

Vargas-Ramirez, M., MeZa-Fernández, N., González-Zárate, A., and Castaño-Mora, O.V. 2007b. Participatory research towards the conservation of the endangered-endemic river turtle Podocnemis lewyana in the upper Magdalena River, Colombia. Final report, 60 pp. http://www.fundacionbiodiversa.org/ proyectos_tortuga.htm.

Vargas-Ramirez, M., Castaño-Mora, O.V., and Fritz, U. 2008. Molecular phylogeny and divergence times of the ancient South American and Malagasy riverturtles (Testudines: Pleurodira: Podocnemididae). Organism, Diversity \& Evolution 8: 388-398.

Williams, E. 1954. A key and description of the living species of the genus Podocnemis (sensu Boulenger) (Testudinata, Pelomedusidae). Bulletin of the Museum of Comparative Zoology $8: 279-295$.

\section{Citation Format for this Account:}

Páez, V.P., Restrepo, A., Vargas-Ramirez, M., and Bock, B.C. 2009. Podocnemis lewyana (Duméril 1852) - Magdalena River turtle. In: Rhodin, A.G.J., Pritchard, P.C.H., van Dijk, P.P., Saumure, R.A.,Buhlmann, K.A.,Iverson, J.B., and Mittermeier, R.A. (Eds.). Conservation Biology of Freshwater Turtles and Tortoises: A Compilation Project of the IUCN/SSC Tortoise and Freshwater Turtle Specialist Group. Chelonian Research Monographs No. 5, pp. 024.1-024.6, doi:10.3854/crm.5.024. lewyana.v1.2009, http://www.iucn-tftsg.org/cbftt/. 